\title{
CHICAGO HOUSING CONDITIONS, VII: TWO ITALIAN DISTRICTS
}

\author{
GRACE PELOUBET NORTON \\ The Chicago School of Civics and Philanthropy
}

Earlier articles in this series have dealt with the housing conditions existing among several of the great immigrant groups of Chicago - the Jews and the Bohemians on the West Side, the Poles and the Lithuanians back of the stockyards, the Poles on the Northwest Side, and the Slavic people clustering about the great steel mills in South Chicago; a more recent article has considered the housing of the Negro in Chicago. This article is to deal with the conditions among another and increasingly large group of immigrants-the Italians. In 1870 there were only 275 Italians in Chicago; in 1900 there were 16,008 . The census figures for I910 are not yet available, but the school census for I9I 2 shows 5,447 minors who were born in Italy and 37,833 who are the children of Italian parents. The largest group of Italians is settled in the Nineteenth Ward, in the district in which Hull House is situated; the second largest settlement is on the Lower North Side in the Twenty-second Ward. The Seventeenth Ward on the West Side, near the Chicago Commons, and the First Ward in the downtown business district each has large numbers.

In I90I, the City Homes Association investigated a large section of the Italian settlement on the West Side. During the present investigation a house-to-house canvass was made on the Lower North Side of the five blocks lying directly north of Chicago Avenue between Sedgwick Street and Gault Court. These blocks are of unequal size; block 3 between Gault Court and Milton Avenue extends from Chicago Avenue to Oak Street, equaling in length blocks I and 2 between Milton Avenue and Townsend Street and blocks 4 and 5 between Townsend Street and Sedgwick Street. The investigation was extended to the district in the First Ward, because of the different type of houses in which the Italians were 
living there. Here a canvass was made of a part of the block on Plymouth Court between Polk and Taylor streets. Both districts are settled by Sicilians and South Italians.

The district on the North Side is popularly known as "Little Sicily" or sometimes as "Little Hell." It is familiar to the average citizen of Chicago because of the "Black Hand" crimes so frequently committed there. During I909 and I910, I9 murders were committed in this district, and six at a certain corner on Milton Avenue, called by the newspapers "death corner." I

It is only fair to explain that although the "Black Hand" crimes may have caused the name to persist, the district was known as "Little Hell" before the Italians settled there. Previous to the great fire, the district lying between North Clark Street and the North Branch of the river was a network of narrow and unimproved roads crowded with poor cottages. The population was chiefly German and Irish. In the fire this district suffered more severely than any other. In the very blocks chosen for this canvass, the fire found its greatest number of victims. Almost immediately following the fire, people crowded into the frame cottages that were erected between the river and North Clark Street, either before the establishment of the fire limits (within which only brick and

$x$ The frequency of these crimes in Chicago and especially in this district in the Twenty-second Ward is shown by the following items taken from the Chicago Tribune for a single month, June, rgrr:

June 8: "Gun fight at 'death corner.' Four Italians exchange shots in Milton Avenue district at eleven o'clock. Police found 2,000 Italians walking in the streets, some crying in fear and others talking excitedly in Italian. Only one man injured."

June ro: "Shots aroused neighborhood of ror I Larrabee Street. Alderman Clettenberg, living there, refused to be aroused. Said there was so much shooting near there, that he paid no attention to it."

June r6: "David Russo shot one block from Milton and Oak Street; supposed to be victim of 'Black Hand.' Had been in this country only three weeks. Slayers went free."

June r9: "Giglio murdered a little after midnight; had fled from police in Italy two years before. Started barber shop at 20r6 West Harrison and lived in Gault Court. Had tried to cast off the Mafia yoke. Threatened by 'Black Hand.' Refused, when dying, to give information."

A more familiar "Black Hand" crime was the kidnaping, in August, rgrr, of Angelo Mareno, a small Italian boy living in Gault Court in one of the very houses included in this canvass. The boy, of course, was eventually found, but not until many threatening notes had been received, signed with the symbol of the "Black Hand" and the whole neighborhood had been thoroughly aroused. 
stone buildings were allowed) or in open defiance of them. It was at this time that the neighborhood was first called "Little Hell," owing to the lawlessness of its residents in the years immediately following the fire. As life again became normal, the Germans and Irish, especially those of the better class, began to move east into cleaner streets and more solidly built homes. Room was thus provided for Danish and Swedish immigrants, and a little later for the Italians who were beginning to find their way to Chicago. The following table shows that while there are still a considerable number of Scandinavians in the neighborhood, the district is becoming predominantly Italian. Table I gives the nationality of the heads of the households in the five blocks for which the canvass was undertaken.

TABLE I

Nationalities of Heads of Households. Lower North Side

\begin{tabular}{|c|c|c|c|c|c|c|c|c|c|}
\hline Block & $\begin{array}{c}\text { Ameri- } \\
\text { can }\end{array}$ & German & Irish & Italian & $\begin{array}{l}\text { Scandi- } \\
\text { navian }\end{array}$ & $\begin{array}{l}\text { Miscel- } \\
\text { laneous }\end{array}$ & $\begin{array}{c}\text { Nation- } \\
\text { ality } \\
\text { Un- } \\
\text { known }\end{array}$ & Total & $\begin{array}{l}\text { Percent- } \\
\text { age of } \\
\text { Italians }\end{array}$ \\
\hline r. $\ldots \ldots \ldots \ldots$ & 9 & 27 & 20 & r68 & 72 & 45 & Io & $35 \mathrm{I}$ & 48 \\
\hline $2 \ldots \ldots \ldots \ldots \ldots$ & 7 & 5 & I2 & II 2 & 35 & ro & - & I8I & 62 \\
\hline $3 \cdots$ & 2 & 3 & I6 & 377 & I I & 6 & 5 & 420 & 90 \\
\hline $4 \cdots$ & I9 & 28 & 46 & $3^{I}$ & 83 & 35 & I3 & 255 & I 2 \\
\hline $5 \ldots \ldots \ldots \ldots \ldots$ & I5 & I9 & 20 & 55 & 98 & I 2 & I 2 & $23 \mathrm{I}$ & 24 \\
\hline $\begin{array}{r}\text { Total.......... } \\
\text { Percentage.... }\end{array}$ & $\begin{array}{r}52 \\
4\end{array}$ & $\begin{array}{r}82 \\
6\end{array}$ & $\begin{array}{r}\mathrm{II}_{4} \\
8\end{array}$ & $\begin{array}{r}743 \\
53\end{array}$ & $\begin{array}{r}299 \\
2 \mathrm{I}\end{array}$ & $\begin{array}{r}108 \\
8\end{array}$ & 40 & $\begin{array}{r}\mathrm{r}, 438 \\
\text { IOO }\end{array}$ & • \\
\hline
\end{tabular}

While the Italians constitute 53 per cent of the population of the entire district investigated, and the Scandinavians, the next largest group, only 2 I per cent, a much larger percentage of Swedes and of Germans than of Italians was found in blocks 4 and 5, the blocks on the east side of the district canvassed. In blocks I and 2 the population was 48 per cent and 62 per cent Italian, and in block 3, which lies between Milton Avenue and Gault Court, 9o per cent Italian. As might be expected, it was found that the greater number of the Italian men were common laborers. ${ }^{\mathrm{I}}$

x Among the members of other nationalities, living in the same neighborhood and often in the same houses with the Italians, a much larger percentage of skilled mechanics was found. Among the Italians 58 per cent of the heads of households were unskilled laborers; among the Germans only I6 per cent and among the Swedes only $2 \mathrm{I}$ per cent. 
In the five blocks canvassed in this district 6,326 persons were living. Table II shows the division of this population into adults and children and into members of the family and lodgers. In this table boys and girls under twelve years are counted as children.

TABLE II

Composition of Block Population. Lower North District

\begin{tabular}{|c|c|c|c|c|c|}
\hline \multirow{2}{*}{ BLOCK } & \multicolumn{3}{|c|}{ NuMber in Families } & \multirow{2}{*}{ LODGERS } & \multirow{2}{*}{$\begin{array}{c}\text { Total } \\
\text { PopULATION }\end{array}$} \\
\hline & Adults & Children & Total & & \\
\hline $\begin{array}{l}\mathbf{1} \ldots \ldots \ldots \\
2 \ldots \ldots \ldots \\
3 \ldots \ldots \ldots \\
4 \ldots \ldots \ldots \\
5 \ldots \ldots \ldots\end{array}$ & $\begin{array}{r}926 \\
484 \\
\mathrm{r}, 080 \\
647 \\
576\end{array}$ & $\begin{array}{l}494 \\
29 \mathrm{I} \\
68 \mathrm{I} \\
263 \\
267\end{array}$ & $\begin{array}{r}\mathrm{r}, 420 \\
775 \\
\mathrm{I}, 76 \mathrm{I} \\
9 \mathrm{ro} \\
843\end{array}$ & $\begin{array}{r}\mathbf{r} 64 \\
66 \\
190 \\
\text { ro7 } \\
90\end{array}$ & $\begin{array}{r}\mathrm{I}, 584 \\
84 \mathrm{I} \\
\mathrm{I}, 95 \mathrm{I} \\
\mathrm{I}, 0 \mathrm{I} 7 \\
933\end{array}$ \\
\hline $\begin{array}{r}\text { Total.... } \\
\text { Percentage. }\end{array}$ & $\begin{array}{r}3,7 \mathrm{I} 3 \\
59\end{array}$ & $\begin{array}{r}\mathrm{r}, 996 \\
3 \mathrm{I}\end{array}$ & $\begin{array}{c}5,709 \\
\ldots\end{array}$ & $\begin{array}{r}6 \mathrm{r} 7 \\
\text { ro }\end{array}$ & $\begin{array}{r}6,326 \\
100\end{array}$ \\
\hline
\end{tabular}

It is important to note the relatively small number of lodgers as compared with most of the other immigrant groups which have been studied in these articles. ${ }^{x}$ Both in South Chicago and back of the yards 27 per cent of the total population were lodgers, as compared with Io per cent among the Italians; in the Jewish district 2I per cent; among the Negroes 3I per cent. Only among the Bohemians on the West Side and the Poles in the Nineteenth Ward was the percentage smaller. We have to deal then with a neighborhood where the inhabitants are living a normal family life. This is evident, too, from the large number of children under twelve. It is of interest that the largest percentage of children was found in block 3, which Table I shows to be the most strictly Italian block of the district.

The prevailing type of house in this district is the two- or threestory frame cottage in a more or less dilapidated state. Interspersed with the wooden cottages are newer three-, four-, and sometimes five-story brick tenements, housing in crowded quarters a

${ }^{x}$ Here, as in other districts, the figures relating to lodgers are an underestimate. Questions about lodgers stimulate a rumor that lodgers are to be forbidden, and lead to the withholding of facts regarding them. 


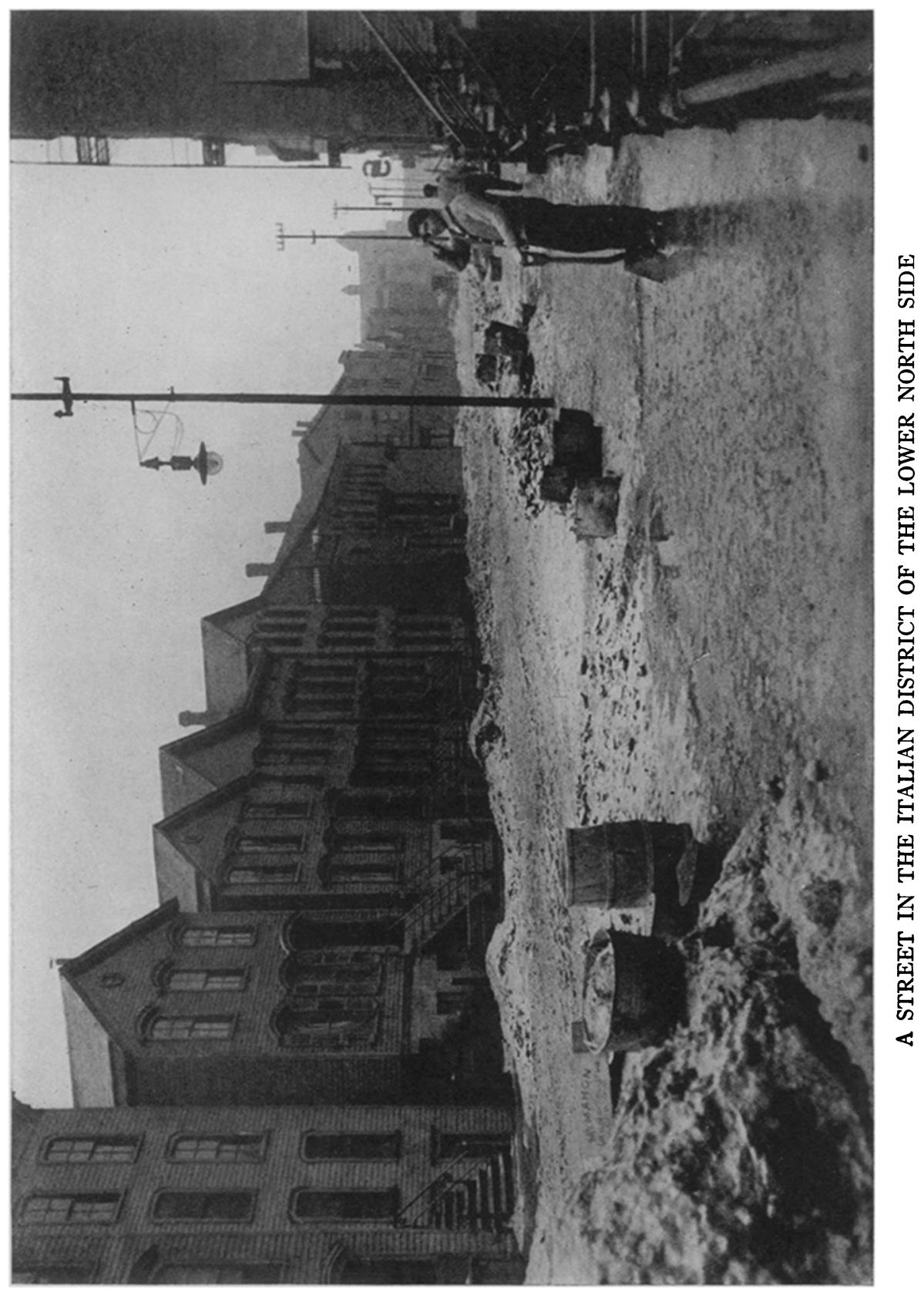

This content downloaded from 080.082.077.083 on March 01, 2018 20:50:54 PM All use subject to University of Chicago Press Terms and Conditions (http://www.journals.uchicago.edu/t-and-c). 
large number of people. ${ }^{x}$ Only I6 per cent of the buildings, however, are over three stories high. A similar condition prevails of course in many parts of Chicago, making a sharp contrast with the high brick tenements of New York. It should be pointed out that although the density per block is less under such conditions as prevail in Chicago, the overcrowding within the houses is apt to be greater.

Of the 404 buildings canvassed, only seven have been built since the tenement law of r902. Only one of these new-law buildings has more than four apartments. This is a brick tenement in block 3 , having eight apartments, varying in size from two to five rooms. Another one of those comparatively new buildings is a one-story brick building, having only a cobbler shop and one room in which the cobbler lives alone. Of the other five, one is brick and one partly brick; two are rear frame houses, and one is in the middle of the lot.

An important fact in connection with the housing is the grade of the yards below the street level. Only four buildings in the whole district have the yard on a level with the street, while 248 ,

I The following tables showing the material of the buildings and the number of stories are of interest in this connection:

TABLE SHOWING NUMBER OF BRICK AND FRAME HOUSES. LOWER NORTH DISTRICT

\begin{tabular}{|c|c|c|}
\hline Material & Number of Houses & Percentage \\
\hline 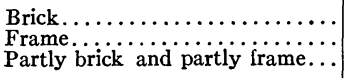 & $\begin{array}{r}108 \\
262 \\
33\end{array}$ & $\begin{array}{r}27 \\
65 \\
8\end{array}$ \\
\hline Total................. & $403^{*}$ & 100 \\
\hline
\end{tabular}

* Material of $\mathrm{I}$ building not reported.

TABLE SHOWING NUMBER OF HOUSES OF SPECIFIED NUMBER OF STORIES. LOWER NORTH DISTRICT

\begin{tabular}{|c|c|c|}
\hline Number of Stories & Number of Houses & Percentage \\
\hline 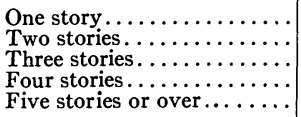 & $\begin{array}{r}41 \\
151 \\
148 \\
56 \\
8\end{array}$ & $\begin{array}{r}10 \\
37 \\
37 \\
14 \\
2\end{array}$ \\
\hline Total............. & 404 & 100 \\
\hline
\end{tabular}

In block 3, which has the largest percentage of Italians, was found a much higher percentage of low frame buildings than in any of the other blocks. 
or 86 per cent, are at least five feet below the street level. This is due of course to the grading of the streets after the erection of the houses. It leads naturally to a rather large number of basement and cellar apartments, which are likely to be dark and damp, although in many, perhaps most, cases, not actually below the level of the yards. Of the I,462 apartments visited, Io 3 were cellar apartments and II7 basement apartments. ${ }^{\mathrm{I}}$ Occasionally this lowest story is boarded up and unused.

The buildings in this district cover a large percentage of the lots as compared with those dealt with in the articles on the stockyards neighborhood or South Chicago. There was considerably more unused space even in the Polish district of the Northwest Side. Only in the Jewish and Bohemian blocks on the. West Side were the lots so crowded. It is especially to be noted that in 25 cases, or 9 per cent, the lot was entirely covered, and in 63 cases, 23 per cent of the entire number, 90 per cent or over of the lot was covered. In some of these lots where nearly all the ground is covered are high brick tenements; more often there are two or even three small frame buildings.

TABLE III

Percentage of Lot Covered

\begin{tabular}{|c|c|c|}
\hline Percentage of Lot Covered & Number of Lots & $\begin{array}{c}\text { Percentage of Total } \\
\text { Number }\end{array}$ \\
\hline 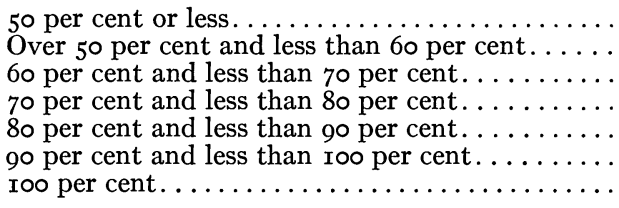 & $\begin{array}{l}37 \\
26 \\
23 \\
62 \\
42 \\
63 \\
25\end{array}$ & $\begin{array}{r}14 \\
9 \\
8 \\
22 \\
15 \\
23 \\
9\end{array}$ \\
\hline Total. & $278^{*}$ & I00 \\
\hline
\end{tabular}

* Eleven not reported.

The crowding of the lot means of course lack of light and air. It also means that the families live much on the street, and that even more than in many other neighborhoods the street is the playground of the children. When in the summer of I9II, two little

I According to the Code a cellar is a story more than half below the level of the street grade, while a basement is a story partly but not more than half below this level. 
children were run over in Gault Court within two weeks, the mayor was induced to close the traffic temporarily, and this block was converted into a street zone for children. Although the experiment has not been repeated, it was an interesting attempt to provide a place in which the children might play, and of course an acknowledgment that for these hundreds of small Italians there was no playground but the street.

As is to be expected in a district where so large a percentage of the lot is covered, the density of population is very high. This is especially true of block I and of block $3{ }^{\mathrm{r}}$ in each of which there were over 400 people to the acre. In blocks 2 and 5 , there were from 320 to 330 people per acre; in block 4, about 235. Table I, it will be remembered, shows that the percentage of the population who are Italians is very much greater in blocks I, 2, and 3 than in blocks 4 and 5 . The two most densely populated blocks then, are ones where the percentage of Italians is high, and it is among the Italians, rather than among the Scandinavians or Irish, that the overcrowding is greatest. How great this overcrowding is, may be shown by a comparison with the density of some other congested districts in Chicago. When the City Homes Association made its investigation, the net area and the number of people per acre was computed for 54 blocks, part of them located in the Jewish and Italian district in the Ninth and Nineteenth wards, part of them in the most crowded section of the Polish neighborhood in the Sixteenth Ward. Forty of these 54 blocks had a density of less than 300. Among them all only two were found having a density as great as blocks $I$ and 3 in this neighborhood; one of these was in the Italian district, one in the Polish.

In order to appreciate the seriousness of the overcrowding, however, it is necessary to take into consideration not only the density per acre, but the type of house in which the people are living. The large percentage of the lot covered, taken together with the shape of the lot prevalent in Chicago, a long, narrow lot, and the fact that so many more of the houses are separate cottages than large tenements, means of course a considerable number of rear houses. The canvass showed in these blocks 289 buildings fronting on the street,

I The net area of each block was used in the computation. 


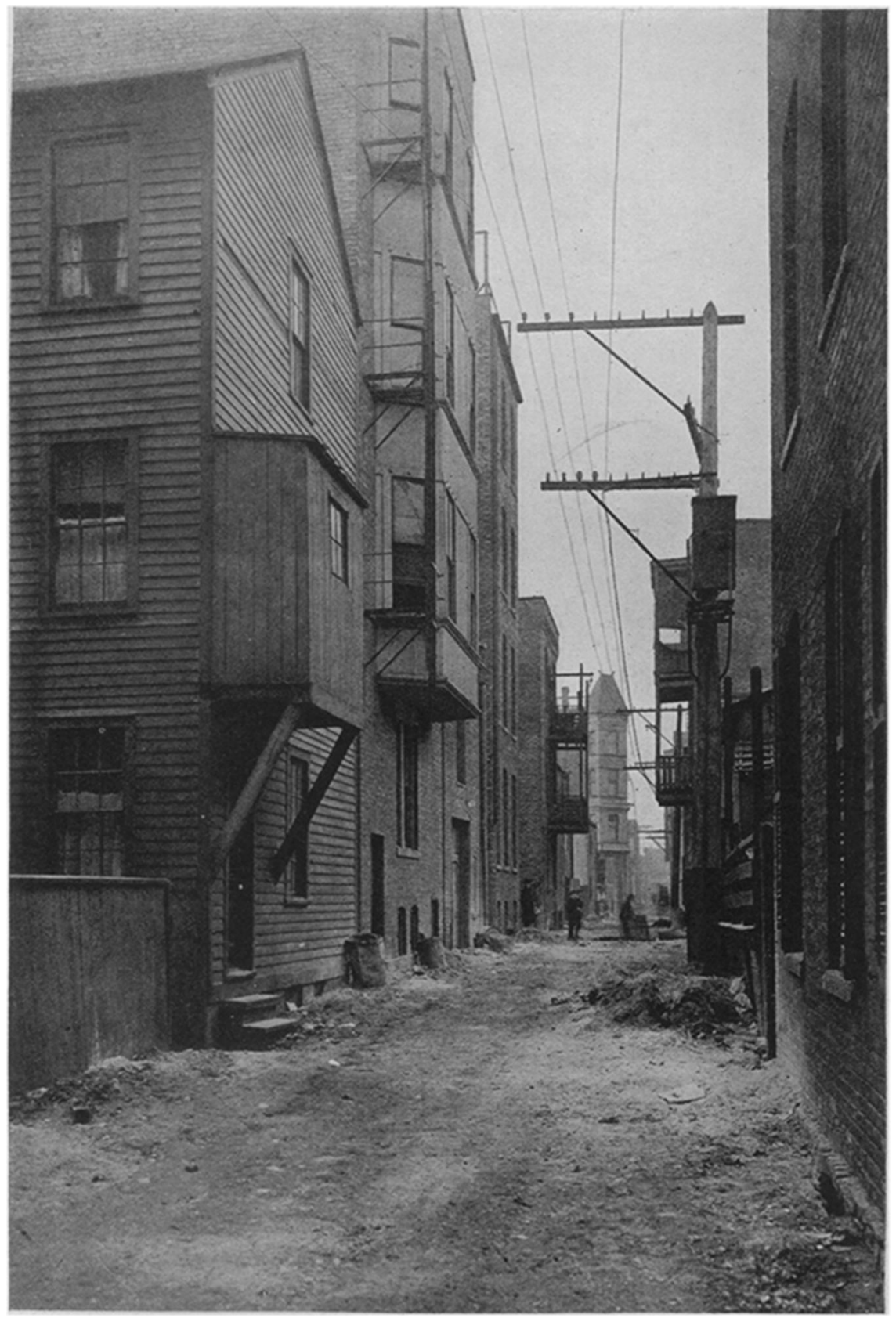

ALLEY TENEMENTS IN THE LOWER NORTH DISTRICT

This content downloaded from 080.082.077.083 on March 01, 2018 20:50:54 PM All use subject to University of Chicago Press Terms and Conditions (http://www.journals.uchicago.edu/t-and-c). 
five buildings in the middle of the lot, and I Io, or 27 per cent of all the buildings, in the rear. These rear buildings are many of them old buildings moved back from the street. The majority of them are frame houses, dark and in poor repair. Only 42 per cent of all the buildings in this district are reported as in good repair. ${ }^{\mathrm{I}}$ In the stockyards district 54 per cent were in good repair; in the Bohemian district 57 per cent, and in the Polish district 7 I per cent.

The large percentage of buildings not in good repair means that hundreds of people in this neighborhood are living in houses where the conditions not only cause great discomfort but are frequently dangerous to the health of the tenants. One of the worst features of the condition of the houses was the damp walls. Frequently the roofs leaked, destroying the ceiling and flooding the floors. In numerous cases the sinks were frozen and the water supply entirely cut off. The landlords refused to make even the most necessary repairs; in one case the tenant could not get a badly leaking gas jet mended. In one apartment the sink was frozen, the window was broken and partly boarded up, and the water-closet above was out of order so that water was flowing through the ceiling into the bedroom. This was in January; the woman said that the landlord promised to make all necessary repairs in May. In this building a baby had died within a few days, and there were three cases of illness, which if not caused by the condition of the house must have been rendered more serious by it. In one case a tenant had applied to the United Charities to help her move from a house in this neighborhood because she considered it unhealthful; within a year there had been seven ambulance calls from that one building. Some of the cellars were so damp that they could not be used; often they were in a condition

$\therefore$ TABLE SHOWING THE STATE OF REPAIR OF HOUSES. LOWER NORTH DISTRICT

\begin{tabular}{|c|c|c|}
\hline State of Repair & Number of Houses & Percentage \\
\hline 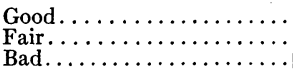 & $\begin{array}{r}166 \\
162 \\
69\end{array}$ & $\begin{array}{l}42 \\
4 \mathrm{I} \\
\mathrm{I} 7\end{array}$ \\
\hline Total.............. & $397^{*}$ & 100 \\
\hline
\end{tabular}

* In 7 cases the state of repair was not reported.

As is to be expected, block 3 , which has the largest number of low frame buildings, has much the smallest percentage in good condition. 
which made them dangerous not only to those living in the cellar apartment but to other occupants of the house. One cellar was flooded and the water had frozen into a solid block of ice so that a small boy said that he would be skating there if the ceiling were not so low. The water seemed to come from a toilet under the sidewalk. As soon as a fire was built in the building, the walls began to steam. The whole place was in very bad repair.

With the dilapidation of the buildings goes a general lack of cleanliness in the yards and alleys. The fact that the yards are below the street level makes it especially easy for them to collect heaps of old papers and rubbish, leaving one at the same time with the impression of a comparatively clean street. In some cases garbage thrown in the back yards gives sickening odors about the rear apartments. Not infrequently the air shafts are filled with rubbish. The photograph on page 520 is typical of the condition of many of the alleys.

Of the 404 buildings in the blocks canvassed the majority were used as residences only, but a large number were tenements combined with a shop, a saloon, or a small store, most frequently a market or a grocery. In 27 such buildings were saloons, two of which had poolrooms; in one tenement was a dance-hall; in another a five-cent theater. To a great extent the restaurants, saloons, and places of amusement frequented by the Italians of this quarter are on Chicago Avenue, the southern boundary of the district canvassed. The saloons and larger stores located on the streets running north and south are most of them near the intersection of these streets with Chicago Avenue.

Table IV shows the number of houses containing one or more families, together with the total number of apartments.

The Code defines a tenement as a building used as a home or residence for two or more families living in separate apartments. According to this table then, all but 53 of the 4 or buildings are tenements and so subject to the provisions of the Tenement Code. The largest percentage of the buildings are the home of two, three, or four families, although frequently put up hurriedly for the use of a single family. A little less than one-fifth of the buildings have six or more apartments. 


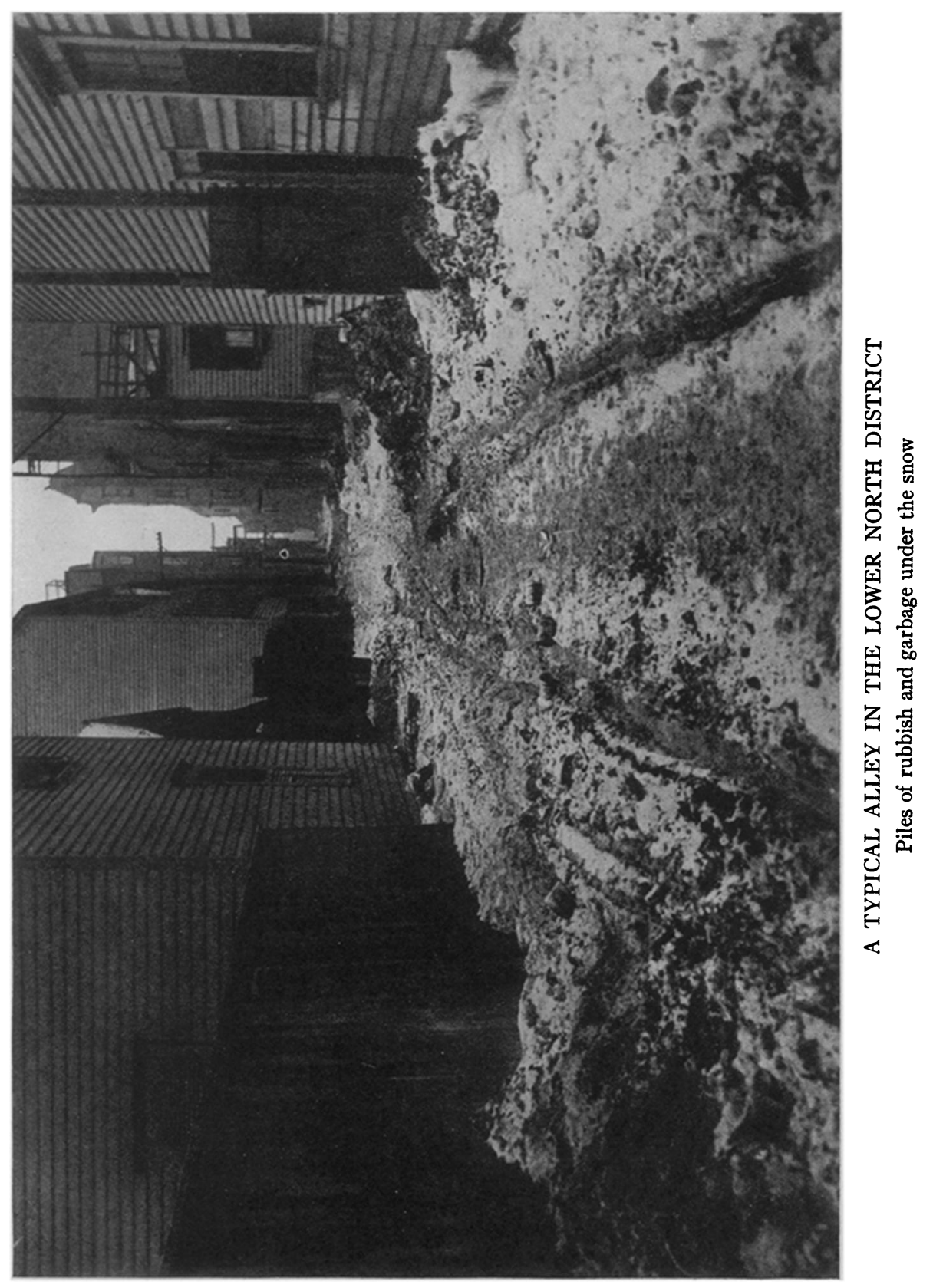

This content downloaded from 080.082.077.083 on March 01, 2018 20:50:54 PM All use subject to University of Chicago Press Terms and Conditions (http://www.journals.uchicago.edu/t-and-c). 
In connection with the number of apartments per buildings, the location of the apartment is of interest. The fact that there were a good many cellar and basement apartments has already been mentioned and accounted for. In one of these damp basement apartments I 2 people were living, an Italian with his wife and six

TABLE IV

Number of Houses Occupied by Specific Number of Families. LOWER NORTH DISTRICT

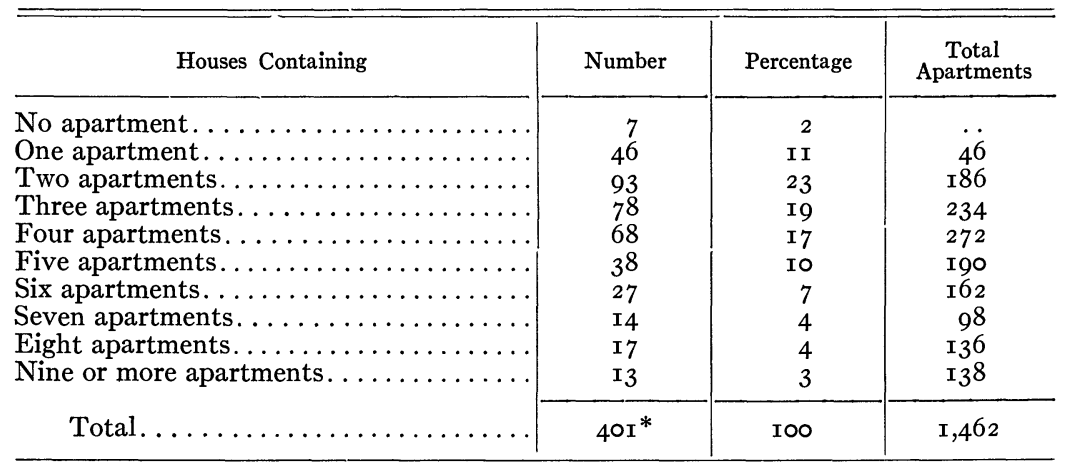

* There was no report as to the number of apartments in 3 buildings.

children, and two old couples, distantly related to them. One of the old ladies who was ill was in a dark bedroom with a dirty window which appeared never to have been opened. From another damp, dark, and rat-ridden basement apartment in this neighborhood, the United Charities has within one year moved three different families. Two hundred and eighty-two of the I,462 apartments were in rear buildings, while 444, or 3I per cent, were rear apartments, some of them in front and some in rear buildings. These rear apartments are likely to be darker, more crowded, and more dilapidated than the front ones. Table $\mathrm{V}$ shows the number of apartments having a specified number of rooms. As in most of the districts visited, the four-room apartment is typical; a very small percentage of the families live in one-room apartments; a considerably larger number, however, 30 per cent of all, have only two or three rooms.

The question of rent is of course an important one in any study of housing conditions. The relation between the rent paid and the 
accommodations secured is shown by Table VI, which gives in detail the rents paid together with the number of rooms. It will be noted that 64 per cent of all the tenants were paying under $\$$ ro.00 a month for rent.

\section{TABLE V}

Apartments Having Specified Number of Rooms. Lower North District

\begin{tabular}{|c|c|c|}
\hline - Apartments Having & Number & Percentage \\
\hline I room $\ldots \ldots \ldots \ldots \ldots$ & I6 & I \\
\hline 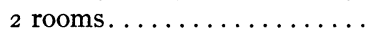 & 142 & Io \\
\hline 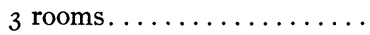 & 277 & 20 \\
\hline 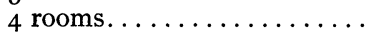 & 566 & 40 \\
\hline 5 rooms. . . . . . . . & 227 & I6 \\
\hline 6 rooms $\ldots \ldots \ldots \ldots \ldots \ldots$ & I60 & I I \\
\hline \multirow{3}{*}{$\begin{array}{r}7 \text { rooms } \ldots \ldots \ldots \ldots \ldots \ldots \ldots \ldots \\
8 \text { or more } \ldots \ldots \ldots \ldots \ldots \ldots \ldots\end{array}$} & I3 & $\mathbf{I}$ \\
\hline & I7 & $\mathbf{I}$ \\
\hline & $\mathrm{I}, 4 \mathrm{I} 8^{*}$ & 100 \\
\hline
\end{tabular}

* In 44 cases the number of rooms was not reported.

TABLE VI

Number of Apartments for Which Specified Monthly Rentals Are Paid Together with Number of Rooms. Lower North District

\begin{tabular}{|c|c|c|c|c|c|c|c|c|}
\hline \multirow{2}{*}{$\begin{array}{l}\text { APARTMENTS HAVING A } \\
\text { MONTHLY RENTAL OF }\end{array}$} & \multicolumn{6}{|c|}{ Number OF RoOMS } & \multirow{2}{*}{ Total } & \multirow{2}{*}{ 离密 } \\
\hline & $\mathbf{I}$ & 2 & 3 & 4 & 5 & $\begin{array}{l}6 \text { or } \\
\text { More }\end{array}$ & & \\
\hline 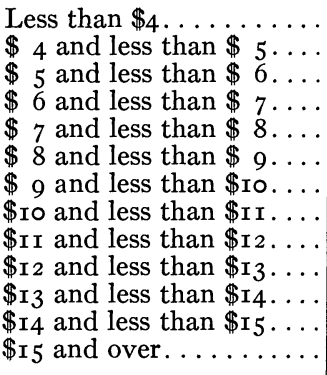 & $\begin{array}{r}4 \\
\mathbf{I} \\
\mathbf{I} \\
\mathbf{I} \\
\cdots \\
\mathbf{I} \\
\cdots \\
\cdots \\
\cdots \\
\cdots \\
\cdots \\
\cdots \\
\cdots\end{array}$ & $\begin{array}{r}17 \\
36 \\
55 \\
5 \\
3 \\
\cdots \\
\cdots \\
2 \\
\cdots \\
\mathrm{I} \\
\cdots \\
\cdots \\
2\end{array}$ & $\begin{array}{r}6 \\
\text { I } 5 \\
77 \\
52 \\
46 \\
37 \\
\text { I } \\
5 \\
\ldots \\
\text { I } \\
\ldots \\
\cdots \\
\text { I }\end{array}$ & $\begin{array}{r}2 \\
4 \\
24 \\
56 \\
66 \\
\text { I I I } \\
80 \\
79 \\
42 \\
28 \\
\text { I0 } \\
5 \\
7\end{array}$ & $\begin{array}{r}\cdots \\
3 \\
6 \\
10 \\
24 \\
19 \\
29 \\
11 \\
37 \\
9 \\
11 \\
23\end{array}$ & $\begin{array}{r}\ldots \\
\ldots \\
\ldots \\
\text { I } \\
\ldots \\
3 \\
2 \\
\text { I7 } \\
7 \\
17 \\
\text { IO } \\
\text { I I } \\
74\end{array}$ & $\begin{array}{l}29 \\
56 \\
\text { I60 } \\
\text { I } 21 \\
\text { I } 25 \\
\text { I76 } \\
\text { I } 2 \\
\text { 132 } \\
60 \\
84 \\
29 \\
27 \\
\text { 107 }\end{array}$ & $\begin{array}{r}2 \\
5 \\
\text { I3 } \\
\text { 10 } \\
\text { 10 } \\
\text { 15 } \\
9 \\
\text { I } \\
5 \\
7 \\
2 \\
2 \\
9\end{array}$ \\
\hline Total............ & 8 & I $2 I$ & $25^{I}$ & $5^{\mathrm{I}} 4$ & I82 & $\mathrm{I} 42$ & $\mathrm{I}, 2 \mathrm{I} 8$ & 100 \\
\hline $\begin{array}{l}\text { Vacant or rent unknown } \\
\text { Apartments owned } \ldots \ldots \ldots \\
\text { No report. . . . . . } \ldots \ldots \ldots\end{array}$ & $\begin{array}{r}6 \\
2 \\
\cdots\end{array}$ & $\begin{array}{r}\text { 16 } \\
5 \\
\cdots\end{array}$ & $\begin{array}{l}\text { I } 2 \\
\text { I } 4 \\
\cdots\end{array}$ & $\begin{array}{l}24 \\
28 \\
\cdots\end{array}$ & $\begin{array}{l}13 \\
32 \\
\cdots\end{array}$ & $\begin{array}{l}\text { 10 } \\
38 \\
\cdots\end{array}$ & $\begin{array}{r}81 \\
\text { I } 19 \\
44\end{array}$ & \\
\hline Total...... & I6 & 142 & 277 & 566 & 227 & I90 & $\mathrm{I}, 462$ & \\
\hline
\end{tabular}


Although the size of the apartment has naturally much to do with the rental, it is evident that the rents do not increase at all uniformly with the number of rooms. We find six-room apartments renting for $\$ 6, \$ 8$, and $\$ 9$, and two- and three-room apartments for $\$_{1} 2, \$_{15}$, and $\$_{1} 6$. It is clear that the location of the apartment must influence the rent to a great extent; it must vary according as the apartment is in the front or the rear building, facing on the street or a passage, on the first or third floor, airy and light, or dark and almost windowless. That it is by no means entirely a matter of the size of the rooms was proved by a detailed study of the rental in connection with the area of the apartment.

A comparison of the rents paid by the Italians of this neighborhood and those paid by other immigrant groups in Chicago is of value. In order to make the comparison fair, the median rents, that is, the points half-way up the scale when the rents are arranged in ascending order, are given for the four-room apartments in each neighborhood, the four-room apartment, being, as already pointed out, the typical one in most of the districts investigated.

TABLE VII

\section{Median Rentals for Four-Room Apartments for Seven Districts}

\begin{tabular}{|c|c|}
\hline Jewish & \$10.00-\$10. 50 \\
\hline Bohemian. & $8.00-8.50$ \\
\hline Polish. & $8.00-8.50$ \\
\hline Stockyards. & $8.00-8.50$ \\
\hline South Chicago. & $9.00-9.50$ \\
\hline Colored. & $12.00-12.50$ \\
\hline & $8.50^{-}$ \\
\hline
\end{tabular}

This table shows that these Italians pay a slightly higher rent in proportion to the number of rooms in their apartments than the Bohemians, Poles, or stockyards laborers, but less than the workers in the steel mills in South Chicago, the Jews on the West Side, or the colored people in the districts canvassed. Specific reasons for the higher rents among these people have been pointed out in earlier articles, the practice of taking lodgers in South Chicago, and the racial exploitation of both the Jews and the Negroes. The slightly higher rents among the Italians may be accounted for by the fact that their work makes it necessary that their homes should 
be near the center of the city, together with their willingness to sacrifice much in order to stay near those of the same race.

Another interesting consideration suggested by a study of the tables showing the rental is the number of families who own their apartments. Only 8 per cent of the families in this district are living in buildings which they own. This is in sharp contrast with the Slavic neighborhoods in two of which 18 per cent of the apartments were owned by tenants. Only among the Negroes, who are usually not permitted to buy their homes, was the percentage so low. Table VIII shows that a large number of these owners have lived in their apartments for many years, while only a small percentage of the tenants as a whole have remained in the same apartment for as long as five years.

\section{TABLE VIII}

Length of Time families Have Lived in Apartments. Lower North DISTRICT

\begin{tabular}{|c|c|c|c|c|c|c|c|c|}
\hline & \multicolumn{7}{|c|}{ Number of Years in Apartment } & \multirow[b]{2}{*}{ Total } \\
\hline & $\begin{array}{c}\text { Less } \\
\text { than } \\
\text { I year }\end{array}$ & $\begin{array}{l}\text { r and } \\
\text { Less } \\
\text { than } 2\end{array}$ & $\begin{array}{l}2 \text { and } \\
\text { Less } \\
\text { than } 3\end{array}$ & $\begin{array}{l}3 \text { and } \\
\text { Less } \\
\text { than } 4\end{array}$ & $\begin{array}{l}4 \text { and } \\
\text { than } 5\end{array}$ & $\begin{array}{l}\text { 5 and } \\
\text { Less } \\
\text { than Io }\end{array}$ & $\begin{array}{l}\text { ro } \\
\text { and } \\
\text { over }\end{array}$ & \\
\hline $\begin{array}{l}\text { Owners......... } \\
\text { Other tenants... }\end{array}$ & $\begin{array}{r}\text { I I } \\
580\end{array}$ & $\begin{array}{r}\text { Io } \\
\text { I } 86\end{array}$ & $\begin{array}{r}\mathbf{1} 4 \\
\mathbf{1} 38\end{array}$ & $9 \stackrel{9}{98}$ & $\begin{array}{r}8 \\
52\end{array}$ & $\begin{array}{r}\text { I3 } \\
\mathbf{1} 24\end{array}$ & $\begin{array}{l}5 \mathrm{I} \\
82\end{array}$ & $\begin{array}{l}\text { I } 6^{*} \\
\text { I,260† }\end{array}$ \\
\hline $\begin{array}{r}\text { Total....... } \\
\text { Percentage.... }\end{array}$ & $\begin{array}{r}591 \\
43\end{array}$ & $\begin{array}{r}\text { I96 } \\
\text { I4 }\end{array}$ & $\begin{array}{r}152 \\
\text { I I }\end{array}$ & $\begin{array}{r}107 \\
8\end{array}$ & $\begin{array}{r}60 \\
4\end{array}$ & $\begin{array}{r}137 \\
\text { I0 }\end{array}$ & $\begin{array}{r}133 \\
\text { I0 }\end{array}$ & $\begin{array}{r}\text { I, } 376 \\
100\end{array}$ \\
\hline
\end{tabular}

*Three cases not reported.

$\dagger 62$ cases not reported and 24 apartments vacant.

As is to be expected in houses such as have been described, the toilet accommodations are inadequate. Although privy vaults have been outlawed since 1894 , nine were found upon the premises canvassed. These were used by i 6 families. Only less offensive are the semi-public toilets which have frequently replaced the vaults. These toilets are situated in the yards, often under the sidewalks, in the halls, and in the basements, and are used by several families in common. In all five blocks only 302 apartments were found with private toilet facilities. The Tenement House Code provides that each apartment must have its own water-closet with the exception of apartments of one or two rooms. This provision affects 
only new-law buildings, however, of which, as has been noted, there are only seven in these blocks. The conditions existing therefore are not illegal but are as dangerous to the health and to the morals of the tenants, especially of the children, as if they were forbidden by law. Two hundred and thirty-seven yard closets were found upon which 536 families were dependent. The condition of these yard closets could hardly be worse. They are dark, dirty, and most frequently out of repair. Also they are often almost inaccessible. Those situated under the sidewalks in some cases can be reached only through a dark passageway through the cellar from the rear of the building. Upon such a closet in one instance 32 persons were dependent; in another instance 34. Upon another premise there were two yard closets, the only toilet accommodation for fourteen families. The menace of such conditions can hardly be overestimated.

The basement and hall closets were also dirty, dark, and poorly ventilated. They were very much out of repair; in many cases the pipes were frozen; in others there were bad leaks. Here, too, large numbers of people were dependent upon one closet. Three cases were found where six families used one hall closet. In one case, the closet on the stairway was frozen and had been locked by the landlord. For two weeks the nine families, 49 persons in all, living in the building had been dependent upon one basement closet, which was also frozen and very dirty. In another case a hall closet was used by a family of five and also by the patrons of a saloon in the same building.

A very much larger percentage of the apartment closets were clean and in good repair than of the more public toilets. In the apartments 28 per cent of the closets were reported as dirty or very dirty, while 22 per cent were in poor repair; of the hall and basement toilets 55 per cent were dirty and 47 per cent out of repair; of the yard closets 60 per cent were dirty (nearly half of these specified as "very dirty") and 58 per cent in poor repair. The difficulty of keeping clean and in order toilets used by so many people and for whom no one feels a special responsibility is evident, and is an additional reason for emphasizing the necessity for each family's having its own toilet within the apartment. 
Since the provisions of the Tenement Code in relation to the overcrowding of rooms, to ventilation, and to light, have been fully treated in an earlier article in this series, ${ }^{1}$ it seems sufficient here to point out violations of the laws in this district, without going into a detailed discussion of the provisions governing them. The Code provides that in neither old-law nor new-law tenements shall an adult person live or sleep in a room without having at least 400 cubic feet of air. That this provision is constantly disregarded is shown by Table IX, which gives the number of adults and children sleeping in one room, together with the cubic contents of the room. In this table buildings of one apartment are excluded, since they are not regulated by the Tenement House Code. Two children are used as the equivalent of one adult, since the law requires for them an equal number of feet of air.

\section{TABLE IX}

Number of Persons Sleeping in Rooms of Specific Cubic Contents. Lower NORTH DISTRICT

\begin{tabular}{|c|c|c|c|c|c|c|c|c|c|c|c|c|}
\hline \multirow[b]{2}{*}{$\begin{array}{c}\text { ConTENTS of Room IN } \\
\text { CUBIC FEET }\end{array}$} & \multicolumn{10}{|c|}{ Number of Rooms Occupied by } & \multirow{3}{*}{ ஜ̇ } & \multirow[b]{2}{*}{ Total } \\
\hline & $\begin{array}{l}\text { :0] } \\
0 \\
0 \\
0 \\
0\end{array}$ & 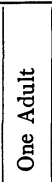 & 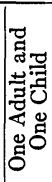 & 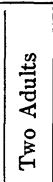 & 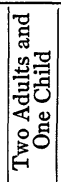 & 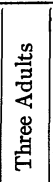 & 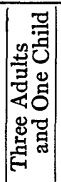 & 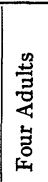 & 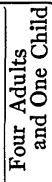 & 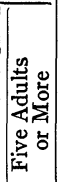 & & \\
\hline Less than $400 \ldots \ldots \ldots \ldots \ldots$ & 3 & 45 & 7 & 29 & 20 & 8 & $\mathbf{I}$ & $\cdots$ & I & $\ldots$ & & I 14 \\
\hline 400 and less than $600 \ldots \ldots$ & I 2 & 240 & 66 & 343 & $\mathrm{I} 43$ & 85 & $I_{3}$ & 4 & $\ldots$ & $\mathbf{I}$ & & 907 \\
\hline 600 and less than $800 \ldots \ldots$. & I 2 & 206 & 59 & $26 I$ & Io9 & 73 & I 2 & I I & 3 & $\ldots$ & కి & 746 \\
\hline 800 and less than $x, 000 \ldots \ldots$ & 7 & IO4 & $3 I$ & 109 & 58 & 28 & 7 & 5 & $\ldots$ & $\mathrm{I}$ & $\mathbb{\pi}_{\pi}^{\pi} \frac{\pi}{2}$ & 350 \\
\hline $\mathrm{I}, \infty \circ 0$ and less than $\mathrm{I}, 200 \ldots \ldots$ & I8 & $8 \mathrm{I}$ & I5 & $5 \mathrm{I}$ & 29 & 28 & 4 & 4 & 3 & $\ldots$ & 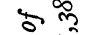 & 233 \\
\hline$I, 200$ and less than $I, 400 \ldots \ldots$ & I7 & 69 & I3 & 43 & 20 & IO & 4 & 3 & $\mathbf{I}$ & $\ldots$ & $ذ$ & I80 \\
\hline $\mathrm{I}, 400$ and less than $\mathrm{r}, 600 \ldots$ & I4 & 50 & I7 & 45 & I2 & 5 & 2 & 2 & $\mathbf{I}$ & $\ldots$ & 胥 & I48 \\
\hline $\mathbf{r}, 600$ and less than $\mathbf{r}, 800$. . & 9 & 35 & 6 & I9 & 5 & 3 & $\ldots$ & I & & & ఏ & 78 \\
\hline I,800 and less than $2,000 \ldots$ & 4 & I 7 & 5 & 8 & 2 & $\mathbf{I}$ & $\ldots$ & . & & & $\overrightarrow{\widehat{s}}$ & 37 \\
\hline $2, \infty 00$ and more $\ldots \ldots \ldots$ & 2 & I2 & $\mathbf{I}$ & I I & & 7 & 2 & $\mathbf{I}$ & $\cdot$ & I & si & 37 \\
\hline Total. & 98 & 859 & 220 & 9 I9 & 398 & 248 & 45 & $3 I$ & 9 & 3 & & 2,830 \\
\hline
\end{tabular}

All the numbers above the leaded line in the table represent cases of illegal overcrowding of the rooms; 49 per cent, that is, of all the persons in this district were sleeping with less than the mini-

I American Journal of Sociology, XVI, No. 4, pp. 449 ff. 
mum amount of air required by law. In some cases, especially in Gault Court, the overcrowding was appalling. In one apartment three adults and three children were sleeping in a room having less than $35^{\circ}$ cubic feet of air, a room that could not legally be occupied even by one adult. In another case an Italian saloonkeeper had six lodgers who slept in a room containing only 504 cubic feet. One Italian family of three adults and three children slept in a room, also used as their parlor, which had only 7 I 8 cubic feet of air. The father was out of work at that time, and the family were taking a lodger who slept in the kitchen, the only other room in the apartment. This overcrowding not only means lack of sufficient air, but also involves a lack of privacy, sometimes of real danger to the morals of the family. It was found that 77 families were using all the rooms in their apartment, even the kitchen, for sleepingpurposes; 399 were using all but one room.

The overcrowding is of course especially objectionable when there are lodgers in the household. Although, as has been pointed out, the lodgers comprise a comparatively small percentage of the population in this district, over 600 were found in all. These were living in 309 of the 1,462 households; that is, $2 \mathrm{I}$ per cent of the families had living with them in their crowded quarters at least one person who was not a member of the family group. It was found that in 65 cases, these lodgers were sleeping with some member of the family. In one case a lodger was sharing a room with a family of seven.

The ordinance makes certain definite requirements in regard to the size of rooms in new-law tenements. No room may be less than 70 square feet in area, less than 8.6 feet high, nor contain less than 400 cubic feet of air. We have seen that II4 rooms used for sleeping did not meet the requirement in regard to cubic contents; this was also true of 72 other rooms. The investigators found $\mathrm{I}, 58 \mathrm{I}$ rooms less than 70 square feet in area and $72 \mathrm{I}$ less than 8.6 feet high. While these conditions, in so far as they exist, as for the most part they do, in old-law buildings, are not illegal, they are definitely below the standard which the community has set for itself, and, as has been pointed out, are more rather than less dangerous than when found in recently built houses. 
The ordinance also attempts to regulate the light and ventilation of the rooms by requiring that each room shall have window space equal to one-tenth of the floor area of the room, and that the windows shall open direct upon a street, alley, yard, or court. These provisions, as so many of the others, do not apply to the oldlaw buildings, and of course were not met in a large percentage of the buildings of this district. The investigators reported 285 rooms as inadequately ventilated; of these 63 had no window at all, 87 had interior windows only; and in the other 135 the outer windows were inadequate for the ventilation of the room. Table $\mathrm{X}$ shows the number of persons, 390 in all, sleeping in these poorly ventilated rooms.

TABLE $\mathrm{X}$

Inadequately Ventilated Rooms and Number of Persons Using. Lower NORTH DISTRICT

\begin{tabular}{|c|c|c|c|c|c|}
\hline \multirow{2}{*}{ Persons } & \multicolumn{4}{|c|}{ Number of Rooms Having } & \multirow{2}{*}{$\begin{array}{c}\text { Total } \\
\text { PERSONS }\end{array}$} \\
\hline & No Window & $\begin{array}{l}\text { Interior } \\
\text { Window }\end{array}$ & $\begin{array}{c}\text { Inadequate } \\
\text { Outer }\end{array}$ & Total & \\
\hline $\begin{array}{l}\text { None. . . } \\
1 \ldots \ldots \\
2 \ldots \ldots \\
3 \ldots \ldots \\
4 \ldots \ldots \\
5 \ldots \ldots \\
7 \ldots \ldots\end{array}$ & $\begin{array}{r}24 \\
19 \\
\text { I5 } \\
4 \\
\text { I } \\
\cdots \\
\ldots\end{array}$ & $\begin{array}{r}27 \\
18 \\
23 \\
\text { I } \\
6 \\
\text { I } \\
\cdots\end{array}$ & $\begin{array}{r}55 \\
20 \\
25 \\
2 \mathrm{I} \\
9 \\
4 \\
\mathrm{I}\end{array}$ & $\begin{array}{r}\text { I06 } \\
57 \\
63 \\
37 \\
\text { I6 } \\
5 \\
\text { I }\end{array}$ & $\begin{array}{r}\cdots \\
57 \\
\text { I } 26 \\
\text { II I } \\
64 \\
25 \\
7\end{array}$ \\
\hline Total.. & 63 & 87 & I35 & 285 & 390 \\
\hline
\end{tabular}

It will be noticed that in four cases three people were sleeping in a windowless room; in one case four people. In another instance where the family of an Italian barber were living in a two-room apartment, four members of the family were sleeping in a room of 646 cubic feet, with the only window opening into the barber shop. In an apartment above a saloon, a few doors south, two adults and three children were sleeping in a bedroom where the only window opened into the parlor, which was also used for sleeping. In another case, eleven Greeks were found living above a stable where several horses were kept. Seven of the men were sleeping in one inadequately ventilated room. The illustration on p. 529 illustrates the manner in which pantries are utilized as bedrooms. 


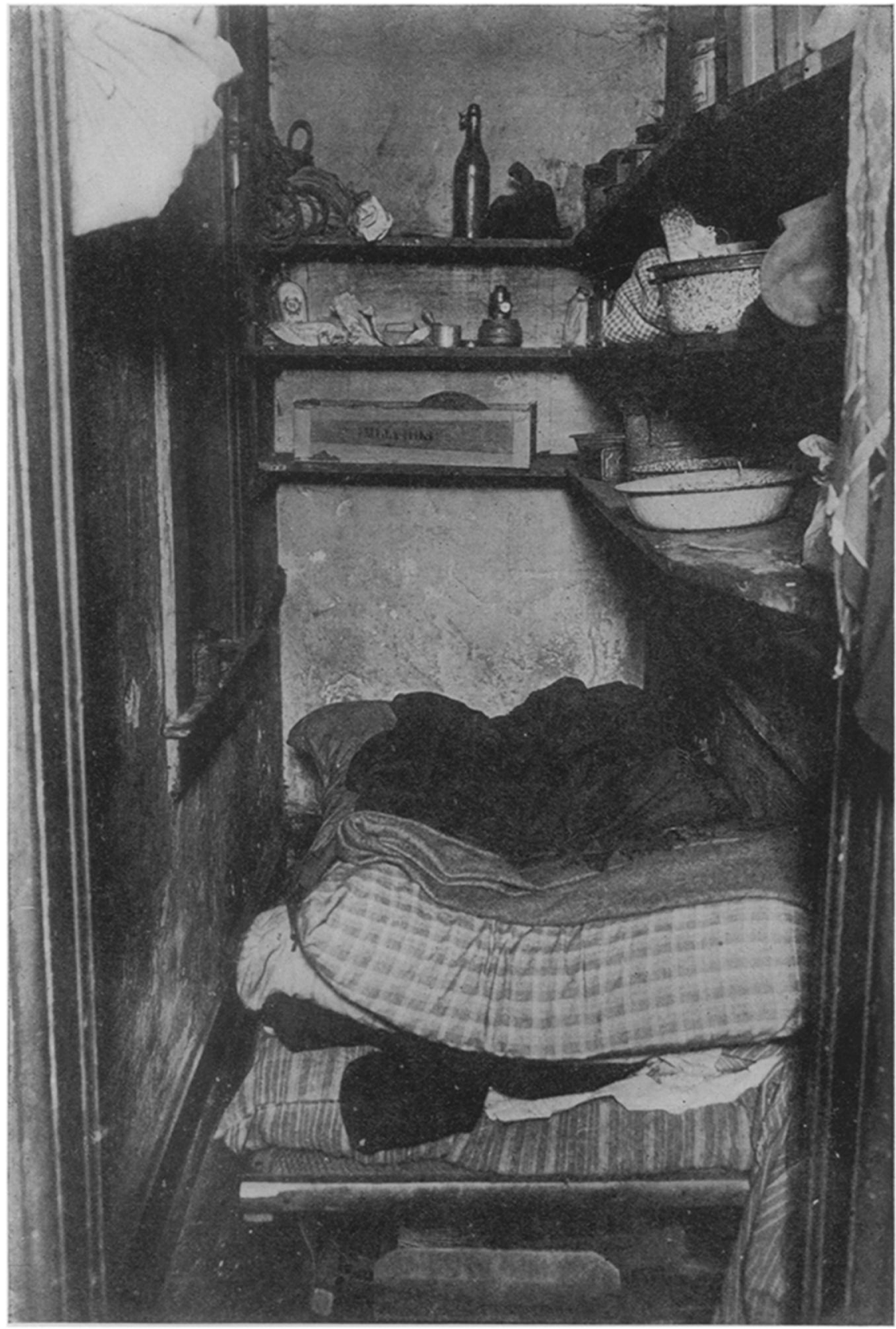

A PANTRY USED BY AN ITALIAN AS A BEDROOM

The window has been boarded up

This content downloaded from 080.082.077.083 on March 01, 2018 20:50:54 PM All use subject to University of Chicago Press Terms and Conditions (http://www.journals.uchicago.edu/t-and-c). 
Eighteen hundred and seven rooms were reported as having insufficient light; of these 459 were called "dark" and I,348 "gloomy." An attempt was made to standardize these terms by using "dark" to apply to rooms where one could read only when close to the window, and "gloomy" when one could read only a few feet away from the window. Only 323 of these rooms failed to comply with the provisions of the code requiring the window space to be equal to ro per cent of the floor area. It is evident, therefore, that the lack of light is due rather to the outlook of the windows than to their size. This outlook is given in Table XI.

\section{TABLE XI}

Outlook of Dark aNd Gloomy Rooms. Lower North District

Number of rooms opening upon-

Another room ................................... 50

Hall.................................... 45

Air shaft or wall .............................. I92

Porch, stairway, or court...................... I35

Passage................................ 1,072

Alley, yard, street, or roof...................... 239

Skylight.................................. 7

Total....................... I,740

Rooms having no windows $\ldots \ldots \ldots \ldots \ldots \ldots \ldots \ldots \ldots \ldots, 6_{3}$

Outlook of windows not reported..................... 4

Total dark and gloomy rooms................ $\overline{\mathbf{r}, 807}$

This table shows that 1,072 , or 63 per cent of all the poorly lighted rooms, open upon a passageway. As was evident from the table showing the percentage of the lot covered, there is very little space between the buildings. The lots are very narrow, and the houses cover nearly the entire width of the lot, leaving passages frequently no more than eight inches or a foot wide. A window opening upon such a passage is practically useless for purposes of either light or ventilation. In one three-room apartment in this neighborhood, a widow was living with four children, the oldest one tuberculous. The front room was light; from this opened the kitchen, very dark because the only window opened directly upon 
the wall of the next house. The third room was long and narrow, the only light and air coming from a window off the small entrance hall. This room was so dark and damp that the family did not use it; all five were living in the parlor and the kitchen.

As was mentioned near the beginning of this article, the conditions found in the block canvassed in the First Ward were markedly different from those in the Lower North district, which we have been discussing. In making comparisons, it is fair to remember that the statistics for the First Ward were based on the canvass of a much smaller neighborhood. Here fifteen premises were canvassed, facing Plymouth Court and backing on the alley between Plymouth Court and State Street. Opposite is the baggage department of the Dearborn Street station, into which come over twothirds of the immigrants arriving in Chicago. Both the street and the sidewalk are very narrow. Near the corner of Polk Street are several buildings not used as dwellings and not included in the canvass; next is a large brick yard, fenced in, but used nevertheless as more or less of a dump; then come the houses canvassed. In this block the nationality of I I 9 heads of households was found. Of these one was a Negro; the other II 8 were Italians. The Negro lived in a house which faced on Taylor Street, and was in the rear of one of the Plymouth Court premises. In the houses facing on Plymouth Court, therefore, the population was entirely Italian. Even block 3 in the Lower North district is less exclusively Italian than this Plymouth Court block. The neighborhood as a whole is, however, a polyglot territory. Just east of Plymouth Court on State Street are many Negroes; to the north are Chinese; at the Jones School, which these Italian children attend, probably more nationalities are represented than in any other school in Chicago.

In the streets of this neighborhood are still standing some of the fine old houses, originally designed for the well-to-do residents of Chicago. These buildings are now used as tenements for large numbers of families. Other buildings were put up as cheap lodginghouses of questionable character, poorly adapted for the use of the families who now live in them. To this group belong the Plymouth Court buildings canvassed. There are also larger and more recently built tenements, some of them covering completely the 


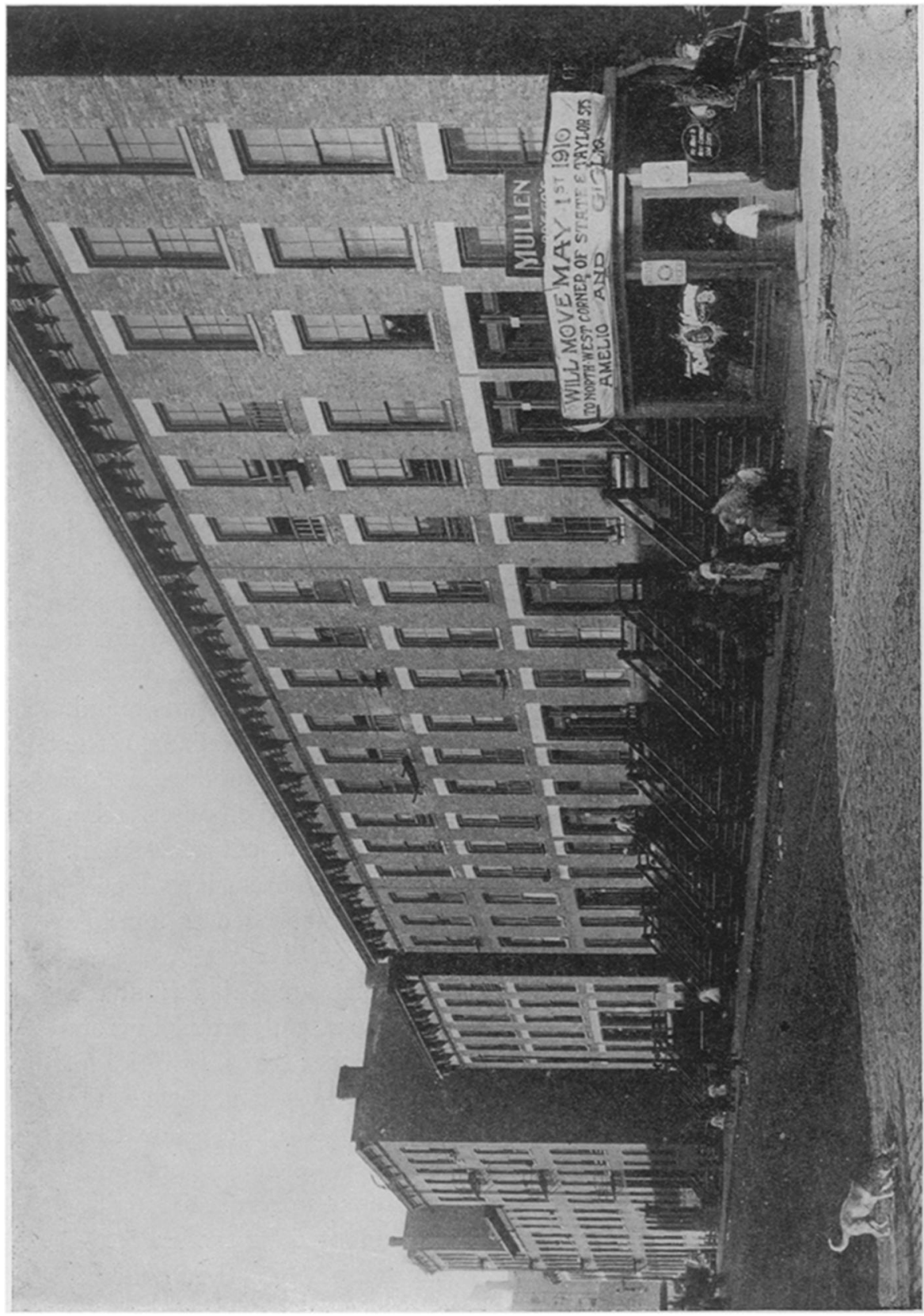

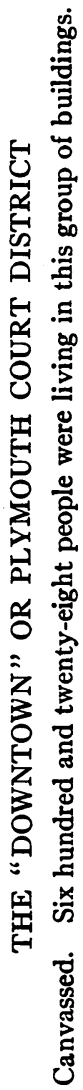

This content downloaded from 080.082.077.083 on March 01, 2018 20:50:54 PM All use subject to University of Chicago Press Terms and Conditions (http://www.journals.uchicago.edu/t-and-c). 
lots upon which they are built. Although the canvass in this downtown district covers only a small territory, it is believed to be typical of a large part of this neighborhood. ${ }^{x}$

Of the fifteen lots canvassed, seven were less than 80 per cent covered by buildings, five were from 80 per cent to $9 \circ$ per cent, and three over 90 per cent. These figures show that so far as congestion is indicated by the percentage of the lot covered, this district is less rather than more crowded than the Lower North district. The type of building, however, is different; we are not dealing with low frame buildings such as housed the Italians on Gault Court. All but one of these buildings were brick, and all that were used as dwellings were at least three stories high. Four of the buildings contained over ro apartments, one of them as many as 16 . In all, there were 123 apartments, 36 of which were in the rear of the building, and 23 in the middle. These brick buildings were in an even more dilapidated condition than the frame buildings of the North Side district; not one was reported by the investigators as in good repair. This is in part due to the fact that there were no new-law houses in the block, that is, no houses that had been built since 1902. In the rear of the lots were a few buildings not used as dwellings; two of these belonged to the fire department; the others were sheds or stables. Two rear buildings were used as dwellings, each having three apartments; the remainder of the buildings faced the street. In one was a store, and in another a saloon; the others were used as residences only. Table XII gives the location of the apartments.

Only 8 per cent of the apartments were found to be basement apartments, and there were no cellar apartments. This is in contrast with the Lower North district, where I 5 per cent of all the apartments were in basements or cellars. It will be remembered, however, that the large number of basement apartments there was accounted for by the grading of the street.

x The district of segregated vice which has now been moved south to Twentysecond Street and the adjoining territory formerly centered in Custom House Place, a block west of Plymouth Court. This whole neighborhood was disreputable, and old maps show that several of the buildings canvassed, where these Italians are now living, were originally houses of prostitution. 
As is perhaps to be expected, the toilet conditions in the block could not well be worse. In only two apartments were there private water-closets; 85 families were dependent upon 22 closets in the halls; the rest upon 12 yard closets. These 36 closets were the only accommodations for 628 people. Not one yard closet was found which was clean or in good repair; some of them were indescribably filthy. One closet which was used by five families was in an outhouse, very dirty and in bad repair and with no door, so that there was absolutely no privacy about it. The hall closets were

TABLE XII

Location of Apartments. Plymouth Court District

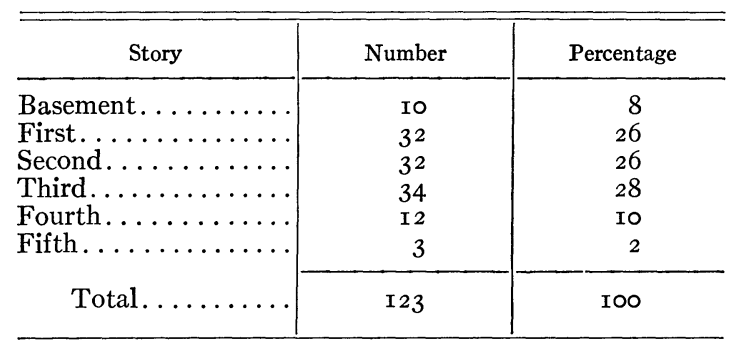

nearly as public and insanitary as the yard closets. In nearly all cases they were dirty, in bad repair, dark, and poorly ventilated. In one building I I families, 4I persons in all, were using one of these hall closets; in another case ${ }_{5}$ families, 73 persons in all, were dependent upon one such closet. Under such conditions it would be impossible for the closets to be in any degree cleanly or sanitary. It would be difficult to overestimate the menace to the health of the people dependent upon them. That there is moral danger as well, especially to the children, was mentioned earlier in this article; it is impossible to describe the conditions in this neighborhood, so much worse even than those found in the Lower North district, without again emphasizing the grave moral dangers to which the children especially are subjected.

In the Italian district on the North Side, it was found that while bath tubs were of course exceptional (IO3 were found in all) nearly every family had a sink, and could, except in the more or less frequent cases where the pipes were frozen or the plumbing out of 
order, avail itself of the opportunities for cleanliness and decency given by running water. In the block on Plymouth Court this was not the case; 8I apartments, 66 per cent of the entire number, were without sinks.

The composition of the population of the district canvassed is shown in Table XIII.

TABLE XIII

Composition of Population. Plymouth Court District

\begin{tabular}{|c|c|c|c|c|c|}
\hline & \multicolumn{4}{|c|}{ Number IN FAMILIES } & \multirow{2}{*}{$\begin{array}{c}\text { TOTAL } \\
\text { POPULATION }\end{array}$} \\
\hline & Adults & Children & Total & Lodgers & \\
\hline $\begin{array}{l}\text { Number...... } \\
\text { Percentage .. }\end{array}$ & $\begin{array}{r}309 \\
49\end{array}$ & $\begin{array}{r}250 \\
40\end{array}$ & $\begin{array}{c}559 \\
\ldots\end{array}$ & $\begin{array}{l}69 \\
\text { II }\end{array}$ & $\begin{array}{l}628 \\
100\end{array}$ \\
\hline
\end{tabular}

It is interesting to compare this table with Table II, which gave the block population for the five blocks on the Lower North Side. We find here a slightly larger percentage of lodgers, and a considerably larger percentage of children-40 per cent instead of $3 \mathrm{I}$ per cent. ${ }^{x}$ Even the 3 I per cent of children is high when compared with that found in the other districts investigated. We have then in this group of buildings 250 children living in quarters which cannot fail to be demoralizing; and we have throughout this downtown neighborhood a population with a large percentage of children growing up under conditions similar to those we are describing.

Although the lodgers formed only I I per cent of the population, they were living in one-fourth of the households. With one exception they were all men, frequently newly arrived immigrants who were either unmarried or had left their families in Italy. In one three-room apartment, a woman who had recently moved away had kept twelve lodgers. In a seven-room basement apartment in which an Italian railroad laborer lived with his wife and two children were fourteen men lodgers, six of whom slept in one poorly ventilated room. In thirteen cases, the lodgers were sharing their bedrooms with one, or more than one, member of the family.

I It will be remembered that "children" as used here does not mean minors, but boys and girls under twelve years. 
Table XIV shows that in this district the apartments are much smaller than in the others investigated. Here it is the two-room rather than the four-room apartment which is typical, while only 23 of the apartments have as many as four rooms, as against 69 per cent in the Twenty-second Ward district.

TABLE XIV

Apartments Having Specified Number of Rooms. Plymouth Court District

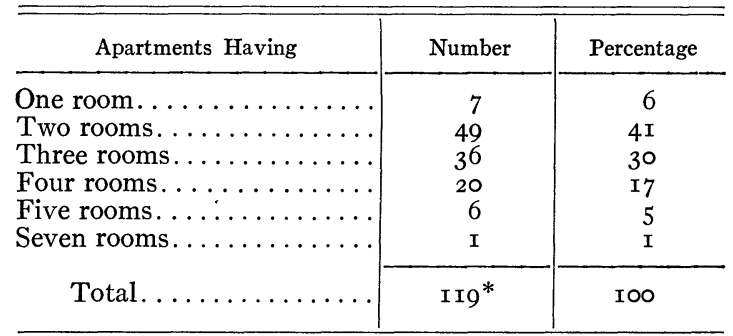

*In 4 cases the number of rooms was not reported.

In a one-room apartment in an adjoining block were living an Italian family with six children, the eldest a sixteen-year-old girl. The building was one of the handsome old brick residences originally used by a single family but now converted into a tenement. Except for the Italian family of eight, living in their one room in the rear of the second floor, the house was occupied entirely by Chinese. The toilet was situated in the hall and used by both the Chinese men and the Italian children. Such crowded living conditions, setting aside the question of race, must have a demoralizing influence upon the children, who live much in the streets in a neighborhood where street influences are dangerous.

The rent per apartment is higher in this block than in the Lower North district if the number of rooms is taken into consideration. In Table XV are given the monthly rentals together with the number of rooms.

It is perhaps hardly fair to make use of the median rental for four-room apartments, since we have the facts for only 20 such apartments. If this is done, however, the median is found to be between $\$ 9.00$ and $\$ 9.50$, higher than that for the Lower North district or for most of the other districts canvassed. If the two- 


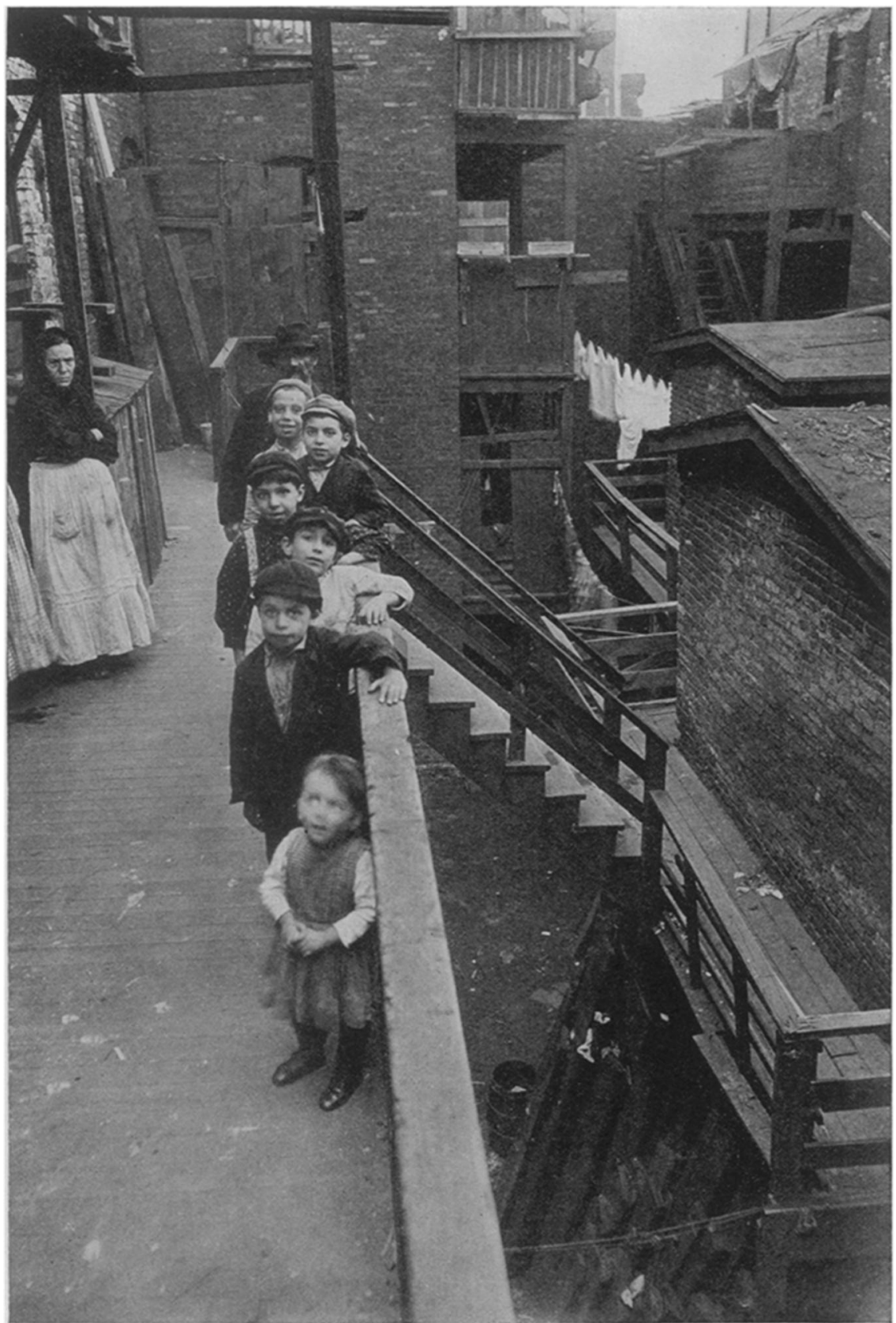

THE REAR OF A TENEMENT HOUSE ON PLYMOUTH COURT

This content downloaded from 080.082.077.083 on March 01, 2018 20:50:54 PM All use subject to University of Chicago Press Terms and Conditions (http://www.journals.uchicago.edu/t-and-c). 
room apartment is considered, as more typical of this neighborhood, the median rental is between $\$ 7.00$ and $\$ 7.5 \circ$; the median rental for two-room apartments on the Lower North side is between $\$ 5.00$ and $\$ 5.50$. The rents, then, in proportion to the accommodations secured, are high. This is, of course, to be expected in a downtown neighborhood in a large city.

TABLE XV

Number of Apartments for Which Specified Monthly Rentals Are Paid Together with Number of Rooms. Plymouth Court District

\begin{tabular}{|c|c|c|c|c|c|c|c|c|}
\hline \multirow{2}{*}{ RENT PER MoNTH } & \multicolumn{6}{|c|}{ NUMBER OF RoOMS } & \multirow{2}{*}{$\begin{array}{c}\text { No } \\
\text { REPORT }\end{array}$} & \multirow{2}{*}{ TotaI } \\
\hline & $\mathbf{I}$ & 2 & 3 & 4 & 5 & 7 & & \\
\hline 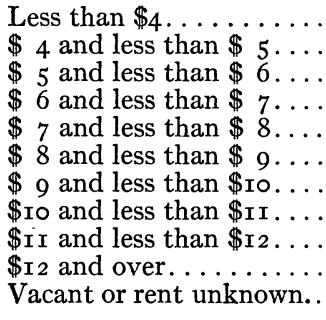 & $\begin{array}{r}4 \\
\mathbf{I} \\
\cdots \\
\mathrm{I} \\
\cdots \\
\cdots \\
\cdots \\
\cdots \\
\cdots \\
\cdots \\
\mathrm{I}\end{array}$ & $\begin{array}{r}\text { I } \\
5 \\
6 \\
8 \\
\mathrm{I} 8 \\
4 \\
6 \\
4 \\
\cdots \\
\\
3\end{array}$ & $\begin{array}{r}\cdots \\
\mathbf{I} \\
7 \\
2 \\
9 \\
3 \\
3 \\
8 \\
\mathrm{x} \\
\cdots \\
2\end{array}$ & $\begin{array}{l}\cdots \\
\cdots \\
\mathbf{I} \\
\mathbf{I} \\
4 \\
3 \\
6 \\
5 \\
\cdots \\
\cdots \\
\cdots\end{array}$ & $\begin{array}{l}\cdots \\
\cdots \\
\cdots \\
\cdots \\
\cdots \\
\cdots \\
\cdots \\
3 \\
\cdots \\
\cdots\end{array}$ & $\begin{array}{l}\cdots \\
\cdots \\
\cdots \\
\cdots \\
\cdots \\
\cdots \\
\cdots \\
\cdots \\
\text { I }\end{array}$ & $\begin{array}{l}\cdots \\
\cdots \\
\cdots \\
\cdots \\
\cdots \\
\cdots \\
\cdots \\
\cdots \\
\cdots \\
4\end{array}$ & $\begin{array}{r}5 \\
7 \\
\mathrm{I} 4 \\
\mathrm{I} 2 \\
3 \mathrm{I} \\
\mathrm{I} \\
9 \\
20 \\
\mathrm{I} \\
3 \\
\mathrm{II}\end{array}$ \\
\hline Total... & 7 & 49 & 36 & 20 & 6 & I & 4 & 123 \\
\hline
\end{tabular}

In contrast with the condition in the Lower North district, where a number of the families are living in apartments which they own, is the fact that this whole block of houses is owned by one of the railroads. In spite of the fact that none of the Italians owns his own house, it was found that 43 of the 123 families had lived in the same apartment at least five years, a very large percentage when compared with that found in the Lower North district shown in Table VIII, or with that in most of the districts investigated. The Italian who once settles in this neighborhood seldom moves out of it. He is near his fellow-countrymen; he is close to the glamor and excitement of South State Street; and he is within walkingdistance of work, so that there is no carfare to pay either for himself or for any member of his family. Ordinarily the possibility of moving into better quarters in another part of the city does not occur to him. The father of an Italian boy who had become an 
habitual truant said that he would like to move into a neighborhood that would be better for his boy, but that rents out near the Parental School were too high. He was surprised to learn that there were other parts of the city where he might live, beside these two districts with which he was acquainted. Frequently the Italians accept such quarters simply because they do not know how to find better. A house-renting bureau such as is conducted by many of the German municipalities would be of great service to the immigrant. ${ }^{\mathbf{x}}$

Table XVI shows that in spite of some extreme cases the Italians on Plymouth Court are sleeping under less crowded conditions than

\section{TABLE XVI}

Number of Persons Sleeping in Rooms of Specified Cubic Contents. Plymouth Court District

\begin{tabular}{|c|c|c|c|c|c|c|c|c|c|c|c|c|}
\hline \multirow[b]{2}{*}{$\begin{array}{l}\text { CONTENTS OF RoOM IN } \\
\text { CUBIC FEET }\end{array}$} & \multicolumn{10}{|c|}{ NUMBER OF Rooms Occupted BY } & \multirow{3}{*}{ 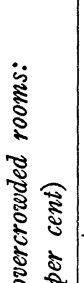 } & \multirow[b]{2}{*}{ Total } \\
\hline & 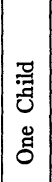 & 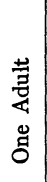 & 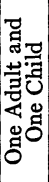 & 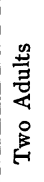 & 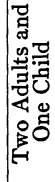 & 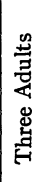 & 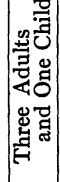 & 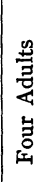 & 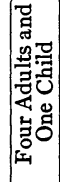 & 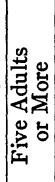 & & \\
\hline 400 and less $t$ & .. & 3 & & & .. & 2 & $\ldots$ & $\cdots$ & & $\ldots$ & & 5 \\
\hline 600 and less than 800. & 2 & 5 & & II & II & I & & $\mathbf{I}$ & & I & & 35 \\
\hline 800 and less than 1,000 . . & $\cdots$ & 5 & 7 & I5 & I2 & 5 & $\mathbf{I}$ & 2 & & $\ldots$ & $\sqrt[m]{2}$ & 47 \\
\hline $\mathrm{I}, \infty 00$ and less than $\mathrm{I}, 200$. & 2 & 7 & & I6 & 6 & 8 & 5 & $\mathbf{I}$ & I & $\mathbf{I}$ & 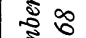 & 50 \\
\hline $\mathrm{I}, 200$ and less than $\mathrm{I}, 400$. & I & 3 & & 9 & 7 & 9 & I & I & & .. & है & $3^{2}$ \\
\hline $\mathrm{I}, 400$ and less than $\mathrm{I}, 600$. & I & 8 & 2 & 4 & 2 & 2 & & & & $\mathbf{I}$ & & 23 \\
\hline $\mathbf{I}, 600$ and less than $\mathrm{r}, 800$. & 2 & 2 & 2 & 4 & $\mathrm{I}$ & 2 & I & & & I & ఫี & I6 \\
\hline $\mathrm{I}, 800$ and less than 2,000 . & .. & 2 & 2 & 2 & $\mathbf{I}$ & I & & & & & & 8 \\
\hline $2, \infty 00$ and more. & .. & 3 & .. & 4 & 2 & 2 & 2 & $\cdots$ & $\mathbf{I}$ & $\cdots$ & & I4 \\
\hline $\mathrm{T}$ & 8 & 38 & 20 & $6_{5}$ & 42 & 32 & I 2 & 7 & 2 & 4 & & 230 \\
\hline
\end{tabular}

those of the Lower North district. Although 68 cases, 30 per cent of the entire number, of illegal overcrowding is far from negligible, it compares favorably with the 49 per cent in the larger district. Perhaps the less overcrowded condition of the bedrooms is partly due to the fact that a larger percentage of the rooms is used for

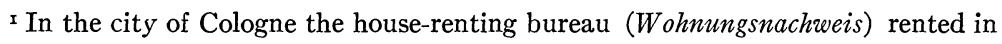
the year rgro-r. over three thousand houses. 


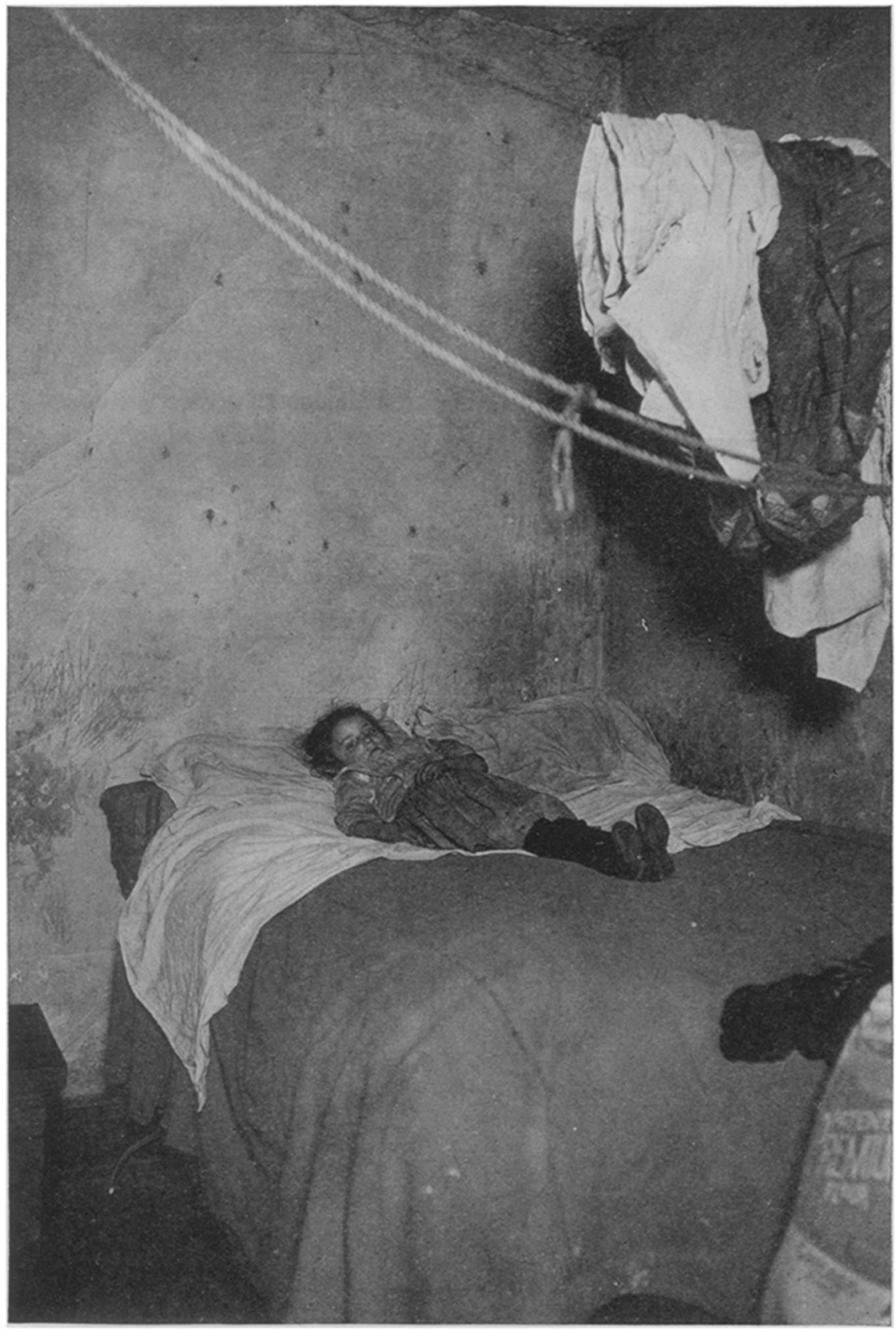

\section{A BEDROOM ON PLYMOUTH COURT}

Three children sleep in this room. The only window opens upon a shaft which is closed at the top.

This content downloaded from 080.082.077.083 on March 01, 2018 20:50:54 PM All use subject to University of Chicago Press Terms and Conditions (http://www.journals.uchicago.edu/t-and-c). 
sleeping purposes; thirty-four per cent of the families utilize every room in the apartment for sleeping.

Forty-six rooms were reported as inadequately ventilated. Table XVII shows that 32 of these rooms were used as bedrooms and that $9 \mathrm{I}$ persons were sleeping in them. Sixteen of the rooms were without any window at all, and in these windowless rooms a total number of $5^{\mathrm{I}}$ persons were sleeping, frequently four or more in one room.

TABLE XVII

Inadequately Ventilated Rooms and Number of Persons Using. Plymouth Court District

\begin{tabular}{|c|c|c|c|c|c|}
\hline \multirow{2}{*}{ 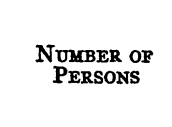 } & \multicolumn{3}{|c|}{ Number of Roous Having } & \multirow{2}{*}{ TotAL } & \multirow{2}{*}{$\begin{array}{c}\text { TOTAL } \\
\text { PERSONS }\end{array}$} \\
\hline & No Window & $\begin{array}{l}\text { Interior } \\
\text { Window }\end{array}$ & $\begin{array}{c}\text { Inadequate } \\
\text { Outer Window }\end{array}$ & & \\
\hline $\begin{array}{l}\text { None...... } \\
\text { One......... } \\
\text { Two....... } \\
\text { Three..... } \\
\text { Four...... } \\
\text { Five....... } \\
\text { Six........ }\end{array}$ & $\begin{array}{l}\ddot{3} \\
3 \\
3 \\
3 \\
3 \\
1\end{array}$ & $\begin{array}{r}\mathbf{I} \\
\cdots \\
2 \\
\mathbf{I} \\
2 \\
\cdots \\
\cdots\end{array}$ & $\begin{array}{r}13 \\
2 \\
5 \\
3 \\
1 \\
1 . \\
\because\end{array}$ & $\begin{array}{r}14 \\
5 \\
\text { I0 } \\
7 \\
6 \\
3 \\
1\end{array}$ & $\begin{array}{r}7 \\
5 \\
20 \\
21 \\
24 \\
15 \\
6\end{array}$ \\
\hline Total.. & I6 & 6 & 24 & 46 & 9 I \\
\hline
\end{tabular}

The investigators reported ror rooms, out of a total of 330 , as dark or gloomy. This was a smaller percentage than was found on the North Side, as might be expected from the fact that a smaller percentage of the lots was covered. Table XVIII gives the out-

\section{TABLE XVIII}

Outlook of Dark and Gloomy Rooms. Plymouth Court District Number of rooms opening upon-

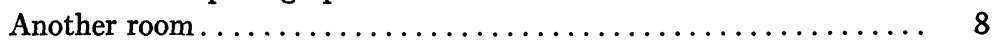

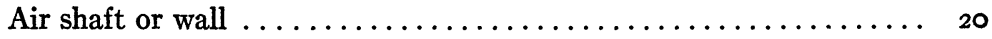

Porch, stairway, or court ....................... ${ }_{3}^{6}$

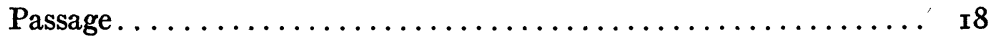

Alley, yard, street, or roof . . . . . . . .

Total............................... 85

No window. ..................................

Total dark and gloomy rooms.................. Iоr 
look of these dark and gloomy rooms. The small percentage which open upon a passage is in sharp contrast with the large number found in the Lower North district; fewer of the houses are built with the long narrow passageways, which form one of the worst features of the housing in the larger district.

An attempt has been made to set down, with no more comment than is necessary to make clear the facts, the conditions which have been found to exist today among the Italians of Chicago in two of their largest settlements. These conditions have not compared favorably even with the worst of those existing among other immigrant groups. The Italian is paying a comparatively high rent for dilapidated, unhealthful quarters. He is living in illegally overcrowded rooms, in damp and gloomy apartments, and under conditions which, if not forbidden in the buildings in which he is living, are prohibited in newer tenements, and thus acknowledged to be dangerous and demoralizing. The facts suggest most clearly that the standard for old buildings in Chicago should be improved. There is no doubt that according to any reasonable standard many of these houses are unfit for human habitation. The community should insist upon a housing code which would make illegal the existence of the most harmful of these conditions. Furthermore, it should provide a staff of inspectors for the Board of Health sufficiently large and efficient to make possible the enforcement of the legislation already passed. Chicago has been criminally negligent in its failure to attend to the housing of its great immigrant groups; it is hoped that the facts set forth in this article may be of aid in arousing the city to a realization of its duty in providing decent houses for the constantly increasing number of foreigners who come to make it their home. 